\title{
IMPLEMENTASI MANAJEMEN MUTU DI SDN PRAMBON
}

\author{
Dyah Indraswati \\ Deni Sutisna \\ PGSD, FKIP, Universitas Mataram \\ E-mail: dyahindraswati@unram.ac.id
}

\begin{abstract}
The purpose of this research is to describe how the implementation of school management to improve the quality of education at SDN Prambon, Dagangan, Madiun. This study uses a qualitative descriptive approach. Data collection techniques are conducted with interviews, observations, and documentation. Indicators developed by researchers as guidelines for data retrieval include school planning, school program implementation, school leadership, and monitoring and evaluation. Data analysis techniques include data reduction, data presentation, and withdrawal of conclusions. The validity test of the data is done by technique triangulation and source triangulation. The education process in Prambon SDN has fulfilled the quality education criteria which includes: 1) The effectiveness of the principal's leadership; 2) active participation of all interested components in the school; 3) The effectiveness of the teaching-learning process; 4) relevant curriculum; 5) Directed vision, mission, and objectives; 6) Conducive school climate and environment; 6) Community involvement and learners parents. The research implication is that the leadership and managerial abilities of principals are imperative to realize effective school management. The quality of education at SDN Prambon has the opportunity to be dynamically and innovatively revised so as to achieve ever increasing quality standards. Improving the quality of education must be carried out continuously and involve all components in schools.
\end{abstract}

Keywords: school management, headmaster, quality of education

Abstrak: Tujuan dari penelitian ini adalah mendeskripsikan bagaimanakah implementasi manajemen sekolah untuk meningkatkan mutu pendidikan di SDN Prambon, Dagangan, Madiun. Penelitian ini menggunakan pendekatan deskriptif kualitatif. Teknik pengumpulan data dilakukan dengan wawancara, observasi, dan dokumentasi. Indikator yang dikembangkan peneliti sebagai pedoman dalam pengambilan data antara lain perencanaan sekolah, pelaksanaan program sekolah, kepemimpinan sekolah, dan pengawasan serta evaluasi. Teknik analisis data meliputi reduksi data, penyajian data, dan penarikan kesimpulan. Uji keabsahan data dilakukan dengan triangulasi teknik dan triangulasi sumber. Proses pendidikan di SDN Prambon sudah memenuhi kriteria pendidikan yang bermutu yang meliputi: 1) keefektifan kepemimpinan kepala sekolah; 2) partisipasi aktif seluruh komponen yang berkepentingan di sekolah; 3) efektifitas proses belajar mengajar; 4) kurikulum yang relevan; 5) visi, misi, dan tujuan yang terarah; 6) kondusifnya iklim dan lingkungan sekolah; 6) keterlibatan masyarakat dan orang tua peserta didik. Implikasi penelitian ini adalah kepemimpinan dan kemampuan manajerial kepala sekolah merupakan keharusan untuk mewujudkan pengelolaan sekolah yang efektif. Mutu pendidikan di SDN Prambon berpeluang untuk direvisi secara dinamis dan inovatif sehingga mencapai kualitas standar yang semakin meningkat. Peningkatan mutu pendidikan harus dilakukan secara berkelanjutan dan melibatkan kerjasama seluruh komponen yang ada di sekolah.

Kata kunci: manajemen sekolah, kepala sekolah, mutu pendidikan 
Menurut Undang-Undang No. 20 Tahun 2003, tujuan pendidikan nasional adalah untuk mengembangkan potensi peserta didik agar menjadi manusia yang beriman dan bertaqwa kepada Tuhan Yang Maha Esa, berakhlak mulia, sehat, berilmu, cakap, kreatif, mandiri, dan menjadi warga negara yang demokratis dan bertanggung jawab (Indraswati, Marhayani, Sutisna, \& Widodo, 2020). Pendidikan memiliki tanggung jawab mempersiapkan peserta didik menghadapi tantangan di masa depan (Widodo, Indraswati, \& Sobri, 2019). Pendidikan juga dipandang sebagai upaya mengembangkan manusia supaya memiliki pengetahuan dan keterampilan (Nur, Harun, \& Ibrahim, 2016). Pendidikan tidak boleh diskriminatif karena tidak sesuai dengan Hak Asasi Manusia (Arif Widodo, Dyah Indraswati, Deni Sutisna, Nursaptini, 2020). Tujuan pendidikan dapat tercapai apabila kualitas lembaga pendidikan terjaga. Ada beberapa indicator yang menjadi tolak ukur keunggulan lembaga pendidikan. Indikator tersebut antara lain proses pendidikan yang berjalan di sekolah, kelengkapan sarana dan prasarana, profesionalisme tenaga pendidik dan sumber daya manusia, prestasi akademik peserta didik dan kualitas manajemen sekolah (Imron, 1998). Dikutip dari kompasiana, manajemen sekolah adalah ujung tombak berhasilnya tujuan pendidikan yang hendak dicapai. Kualitas pendidikan di Indonesia diukur dengan delapan standar yang meliputi standar isi, standar proses, standar komptensi lulusan, standar pendidik dan tenaga kependidikan, standar sarana dan prasarana, standar pengelolaan, standar pembiayaan dan standar penilaian pendidikan.

Pendidikan dasar merupakan kebutuhan dasar masyarakat, sehingga mutu pendidikan dasar harus menjadi perhatian semua pihak. Keefektifan manajerial kepala sekolah menghasilkan mutu pendidikan yang berkualitas. Manajemen sekolah harus mampu menjadikan sekolah sebagai lembaga yang menyiapkan generasi yang memiliki kemampuan fisik, kognitif, dan karakter yang baik sehingga nantinya peserta didik mampu berperan di dalam masyarakat (Dyah Indraswati, Arif Widodo, Aisa Nikmah Rahmatih, Mohammad Archi Maulyda, 2020). Manajemen sekolah sangat berperan penting dalam ketercapaian mutu sekolah. Manajemen sekolah merupakan penyelarasan sumber daya yang dilakukan secara mandiri oleh sekolah dengan melibatkan semua kelompok yang terkait dengan sekolah dalam pengambilan keputusan untuk mencapai visi, misi, dan tujuan sekolah. Kepala sekolah memiliki peran penting dalam mengatur jalannya manajemen sekolah. Kepala sekolah perlu memiliki kemampuan memahami dan mengatur sumber daya, mengambil keputusan, berdemokrasi, berkomunikasi, restrukturisasi kebijakan, memperbaiki kondisi yang tidak baik, dan memilih cara pelaksanaan (Usman, 2014). Pencapaian mutu bukan hanya menjadi tanggung jawab kepala sekolah saja tetapi tanggung jawab semua yang terlibat dalam organisasi sekolah seperti komite sekolah, dinas pendidikan, guru, tata usaha, peserta didik, orang tua, dan masyarakat (Asep Sunandar, Sunarni, 2013).

Sekolah harus memiliki perencanaan yang merujuk pada progam kerja jangka pendek, jangka menengah dan jangka panjang (Deni Sutisna, Dyah Indraswati, Nursaptini, Setiani Novitasari, 2020). Keberhasilan sekolah merujuk kepada kepemimpinan dalam administratif pengajaran, koordinasi program pembelajaran, dan kebijakan tentang standar akademik (Wellisch, Macqueen, Carriere, \& Duck, 1978). Pemimpin dalam hal ini kepala sekolah harus mampu bekerja sama dengan warga sekolah berdasar visi yang sama supaya tercipta praktik yang menjadi kunci peningkatan mutu sekolah (Sukaningtyas, Satori, \& Udin Syaefuddin 
Sa'ud, 2016). Sepuluh nilai sekolah yang relevan dalam penjaminan mutu pendidikan antara lain: (1) aturan dalam pencapaian visi sekolah; (2) pengembangan profesionalitas guru; (3) komitmen pada perbaikan mutu pembelajaran; (4) komitmen meningkatkan mutu pendidikan; perbaikan mutu secara berkelanjutan; (6) komunikasi terbuka; (7) nilai dan budaya sebagai landasan proses pendidikan; (8) peningkatan hasil belajar; (9) inovasi pembelajaran; (10) apresiasi pada prestasi peserta didik.

Kepala sekolah harus memahami perubahan paradigma dalam kurikulum terbaru, dimana sekarang pembelajaran lebih berpusat pada peserta didik (Widodo \& Indraswati, 2019). Guru terbiasa melaksanakan pembelajaran inovatif apabila ada campur tangan kepala sekolah dalam memberikan pendampingan dan kepedulian (Riyanta, 2016). Kepala sekolah perlu memantau agar pelaksanaan pembelajaran dapat memperkuat pendekatan ilmiah yang membuat peserta didik dapat berpikir kritis, logis, dan dapat memecahkan masalah dengan inovatif dan kreatif (Indraswati, 2018). Kepala sekolah perlu melakukan monitoring dan pengujian mutu pendidikan (Sutisna, Indraswati, \& Sobri, 2019). Tim peneliti Stanford University, Amerika Serikat, melakukan pengamatan terhadap 1.800 sekolah di tujuh negara dan menemukan fakta bahwa hampir $50 \%$ perbedaan sekolah dengan performa tinggi dan rendah ditentukan kualitas kebijakan kepala sekolah. Di Indonesia, peran kepala sekolah masih dianggap sebagai pekerja administrative yang kurang terlibat dalam perbaikan pengajaran. Daniel Suryadarma, anggota tim penelitian SMERU, melakukan penelitian di 20 SDN dan 5 madrasah di Karawang menemukan $60 \%$ lebih dari 25 kepala sekolah mengemukakan targetnya adalah memastikan siswa kelas VI lulus dengan nilai ujian yang baik. Hanya sekitar
$20 \%$ kepala sekolah yang memiliki semangat membenahi kualitas proses pembelajaran di kelas (The Conversation, 2020).

Mutu pendidikan mencakup input, proses, dan output. Input merupakan sesuatu yang harus tersedia agar sebuah proses dapat berlangsung. Proses merupakan perubahan kearah lebih baik dengan pengintegrasian input ke dalam situasi pembelajaran yang kondusif dan efektif. Output merupakan hasil kerja sekolah yang dapat diukur kualitas, kuantitas, inovasi, dan produktivitasnya (Fitrah, 2017). Salah satu usaha peningkatan mutu pendidikan adalah peningkatan mutu manajemen sekolah (Pasaribu, 2017).

Penelitian yang dilakukan oleh (Sastradiharja, 2019) tentang prinsip implementasi manajemen sekolah berbasis mutu antara lain: perbaikan secara terusmenerus, menentukan standar mutu, perubahan kultur sekolah, perubahan organisasi, memperkuat program unggulan sesuai dengan kekhasan dan kearifan local, dan mempertahankan kepuasan pelanggan. Berdasarkan acuan ini peneliti melakukan penelitian di SDN Prambon, Dagangan, Madiun untuk melihat penerapan manajemen sekolah mulai dari perencanaan, pelaksanaan program, kepemimpinan sekolah, dan pengawasan serta evaluasi. Dengan demikian dapat di ketahui bagaimana situasi dan kondisi sekolah, kultur sekolah, kekuatan, kelemahan, peluang, dan ancaman.

Tujuan dari penelitian ini adalah mendeskripsikan implementasi manajemen mutu di SDN Prambon, Dagangan, Madiun. Peneliti ingin melihat bagaimana manajemen di SDN Prambon selama ini meningkatkan dan mempertahankan kualitas mutu pendidikannya sesuai dengan standar pendidikan nasional. Penelitian ini bermanfaat bagi pengambilan keputusan dan kebijakan, memilih strategi dan 
memecahkan persoalan sesuai dengan tujuan pendidikan yang ingin dicapai sehingga peningkatan mutu dapat dilaksanakan decara terus-menerus dan berkesinambungan. Mutu sekolah yang bagus mengindikasikan bahwa sekolah memberi kepuasan bagi siswa, orang tua, dan masyarakat

\section{METODE}

Penelitian ini menggunakan pendekatan deskriptif kualitatif. Subjek penelitian ini adalah SDN Prambon, Kecamatan Dagangan, Kabupaten Madiun, Jawa Timur. Pengambilan data dilakukan pada kepala sekolah dan dua orang guru di SDN Prambon. Teknik pengumpulan data dilakukan dengan wawancara, observasi, dan dokumentasi. Indikator yang dikembangkan peneliti sebagai pedoman dalam pengambilan data antara lain perencanaan sekolah, pelaksanaan program sekolah, kepemimpinan sekolah, dan pengawasan serta evaluasi. Teknik analisis data meliputi reduksi data, penyajian data, dan penarikan kesimpulan. Uji keabsahan data dilakukan dengan triangulasi teknik dan triangulasi sumber.

\section{HASIL DAN PEMBAHASAN}

Penelitian dilakukan di SDN Prambon, Kecamatan Dagangan, Kabupaten Madiun, Jawa Timur. Data yang diperoleh per Maret 2020 jumlah guru dan tenaga pendidik sebesar 11 orang dan jumlah keseluruhan peserta didik sebesar 83 peserta didik. Kajian penerapan manajemen sekolah di SDN Prambon sebagai berikut.

\section{Perencanaan Program Sekolah}

Agar kualitas dan pelaksanaan kegiatan di sekolah dapat terarah maka perlu dibuat perencanaan program sekolah.

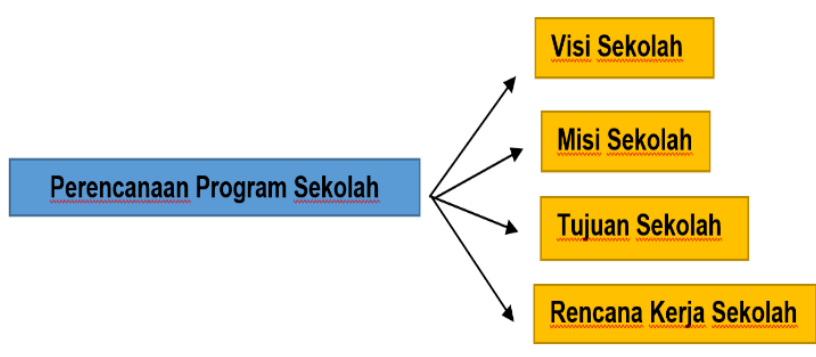

Gambar 1. Indikator Perencanaan Program Sekolah

Indikator dalam perencanaan sekolah tercermin dalam:

a. Visi Sekolah

SDN Prambon memiliki visi yang jelas yang dapat dilihat baik di ruang guru maupun ruang kepala sekolah. Visi SDN Prambon adalah "Terwujudnya warga sekolah yang beriman dan bertaqwa Kepada Tuhan Yang Maha Esa, berprestasi, berbudi pekerti, berbudaya dan peduli lingkungan". Visi sekolah merupakan harapan dan citacita warga sekolah yang dirumuskan secara bersama-sama oleh dinas pendidikan, tokoh masyarakat, komite sekolah, dan dewan guru yang kemudian disosialisasikan kepada seluruh warga sekolah. Visi sekolah tidak setiap tahun diganti, apabila masih dirasa relevan sesuai dengan perkembangan zaman maka akan dipertahankan.

b. Misi Sekolah

Misi merupakan tindakan yang dijadikan arahan untuk mewujudkan visi sekolah (Calam \& Qurniati, 2016). Misi yang dibangun oleh SDN Prambon antara lain:

1) Mewujudkan kompetensi siswa agar menjadi manusia yang beriman dan bertaqwa kepada Tuhan Yang Maha Esa.

2) Mewujudkan prestasi belajar siswa yang tinggi dan memupuk bakat dan minat masing - masing.

3) Melaksanakan pembelajaran yang berorientasi pada pengembangan 
akhlak mulia, kecerdasan akademik dan berfikir analisis.

4) Mewujudkan peningkatan kompetensi guru dan pengembangan ilmu pengetahuan dan teknologi dan mampu mengekspresikan keindahan dan harmoni.

5) Mewujudkan lingkungan sekolah yang sehat, bersih, rindang, dan asri sebagai upaya dalam pelestarian dan pengelolaan lingkungan hidup.

6) Mewujudkan pendidikan budaya dan karakter bangsa yang berwawasan nasional maupun internasional dengan tetap mempertahankan budaya bangsa.

Misi sekolah dirumuskan berdasarkan masukan dari segenap warga sekolah dan pihak yang berkepentingan. Misi sekolah merupakan acuan dari program-program sekolah, dan disosialisasikan kepada warga sekolah melalui papan pengumuman dan rapat pleno.

c. Tujuan Sekolah

Tujuan sekolah termuat dalam dokumen kurikulum sekolah. Dalam penyusunan tujuan sekolah, masukan dari berbagai pihak termasuk komite sekolah sangat dipertimbangkan. Sekolah meminta masukan kepada warga sekolah dengan membagikan form kuisioner untuk diisi kemudian dibahas bersama. Sekolah senantiasa menyampaikan tujuan sekolah setiap ada pertemuan paguyuban dan komite. Mengacu pada visi dan misi sekolah, serta tujuan umum pendidikan dasar, tujuan sekolah dalam mengembangkan pendidikan adalah sebagai berikut ini.

1) Meningkatkan nilai rata-rata UN dari 80.1 menjadi 80.5.

2) Siswa berprestasi dalam bidang olympiade MIPA.

3) Tercapainya Tahfidz Juz 'Amma 20\% dari seluruh siswa dan 15 hafalan surat-surat pendek untuk kelas 1 dan 2.
4) Siswa menjalankan dasar-dasar pendidikan keagamaan diwujudkan dengan sholat 5 waktu mengamalkannya dalam kehidupan sehari-hari.

5) Tercapainya kompetensi guru yang profesional lewat pendidikan dan pelatihan (diklat) penyetaraan $\mathrm{S} 1$ yang linier dari semua personil.

6) Membudayakan semboyan "7S" (Senyum, Salam, Sapa, Sopan, Santun, Sabar, Syukur).

7) Terwujudnya sekolah yang asri (aman, sejuk, rindang, indah).

d. Rencana Kerja Sekolah

Sekolah membuat perencanaan program yang termuat dalam dokumen Rencana Kegiatan dan Anggaran Sekolah (RKAS). RKAS yang disusun merupakan penjabaran Undang-undang Republik Indonesia Nomor 20 Tahun 2003 tentang Sistem Pendidikan Nasional dan Peraturan Pemerintah Nomor 32 tahun 2013 tentang Standar Nasional Pendidikan. Ketentuan yang dibuat berdasarkan 8 Standar Nasional Pendidikan. Standar Nasional Pendidikan (SNP) terdiri atas standar kompetensi lulusan, standar isi, standar proses, standar pendidikan dan tenaga kependidikan, standar sarana dan prasarana, standar pengelolaan, standar pembiayaan pendidikan dan standar penilaian pendidikan. Penyusunannya yaitu dengan cara setiap kegiatan pada satuan pendidikan dikelola atas dasar Rencana Kerja Sekolah (RKS) yang merupakan penjabaran rinci dari Rencana Kerja Jangka Menengah (RKJM) satuan pendidikan yang meliputi masa empat tahun, dan diterapkan dalam Rencana Kerja Tahunan (RKT) dan dengan melihat Raport Mutu dari LPMP agar 8 standar yang belum tercapai dapat tercapai.

Berdasarkan analisis peneliti, perencanaan program dalam manajemen SDN Prambon, Dagangan, Madiun menghasilkan visi, misi, dan tujuan yang dibutuhkan oleh sekolah. Seluruh pihak 
yang berkepentingan seperti dinas pendidikan, tokoh masyarakat, dewan guru, dan komite sekolah ikut merumuskan visi, misi, dan tujuan sekolah. Visi, misi, dan tujuan juga disosialisasikan kepada seluruh warga sekolah melalui pertemuan paguyuban dan rapat pleno. Seluruh rencana program sekolah termuat dalam dokumen Rencana Kegiatan dan Anggaran Sekolah (RKAS). RKAS disesuaikan dengan 8 standar nasional pendidikan untuk menjaga mutu dan kualitas sekolah.

\section{Pelaksanaan Program Sekolah}

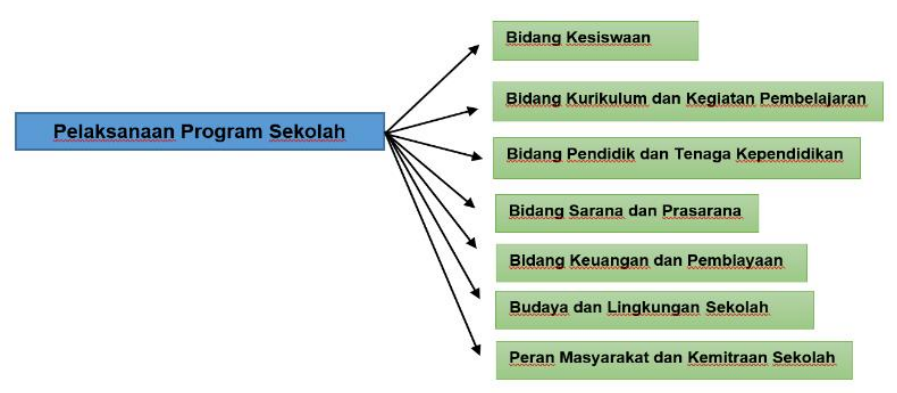

Gambar 2. Indikator Pelaksanaan Program Sekolah

\section{Bidang Kesiswaan}

Sekolah membuat petunjuk penerimaan siswa baru. Ruangan kelas cukup untuk menampung semua siswa dengan layak artinya jumlah siswa sesuai dengan daya tampung sekolah. Sekolah juga berupaya meningkatkan fasilitas untuk memberikan pelayanan terbaik bagi siswa. Terdapat layanan konseling yang dilakukan oleh wali kelas kepada siswa. Terkait dengan kedisiplinan, guru olahraga juga senantiasa memberikan konseling kepada siswa. Di bidang akademik, ada pembinaan bagi siswa yang akan mengikuti lomba olimpiade dan siswa kelas VI yang akan menghadapi ujian nasional.

\section{Bidang Kurikulum dan Kegiatan Pembelajaran}

Sekolah menyusun dan memiliki dokumen kurikulum. Penyusunan kurikulum di tingkat SD dikoordinasi, disupervisi, dan difasilitasi oleh dinas pendidikan kabupaten Madiun. Sekolah juga menyusun kalender pendidikan. Sekolah menyusun silabus berdasarkan kurikulum yang berlaku di Indonesia. Setiap guru bertanggung jawab menyusun dan mengembangkan silabus dan RPP sesuai dengan mata pelajaran yang diampu. Sekolah mengadakan ulangan, remedial, ujian kenaikan kelas, dan ujian akhir sekolah berstandar nasional. Sekolah menjamin mutu kegiatan pembelajaran untuk setiap mata pelajaran dengan menekankan kepada guru untuk menguasai 4 kompetensi yaitu kompetensi pedagogik, profesional, sosial, dan kepribadian.

Guru merencanakan pembelajaran di kelas dengan menyiapkan perangkat pembelajaran lengkap, seperti absensi, silabus, RPP, dokumen penilaian dan sebagainya. Guru harus bisa membuat lingkungan belajar yang menginspirasi, proses belajar yang efektif dan menyenangkan, sumber belajar dan bantuan belajar yang siap siaga. Guru harus mampu menyiapkan layanan belajar yang tepat bagi siswa supaya mereka dapat mengembangkan potensi diri dengan optimal (Arif Widodo, Dyah Indraswati, 2020). Sekolah menyusun program penilaian hasil belajar yang dijadikan pedoman oleh semua guru dan melaporkannya hasil belajar siswa kepada wali murid saat pembagian rapor. Sekolah juga menyusun dan menetapkan peraturan akademik.

\section{Bidang Pendidik dan Tenaga Kependidikan}

Sekolah menyusun program pendayagunaan pendidik dan tenaga kependidikan dengan membentuk Tim pengembangan sekolah. Pengangkatan pendidik dan tenaga kependidikan tambahan di sekolah untuk Guru Tidak Tetap (GTT) dan Pegawai Tidak Tetap 
(PTT) / Tenaga honorer dengan pembukaan lowongan dan sk kepala sekolah.

Ukuran pengaruh atas kebijakan sekolah terhadap guru mencakup 6 item antara lain: kebijakan kedisiplinan, menentukan konten program dalam jabatan, mempekerjakan guru tetap baru, memutuskan bagaimana anggaran sekolah digunakan, mengevaluasi guru, dan kurikulum (Stockard \& Lehman, 2004).

Tetapi untuk peraturan pemerintah saat ini tidak memperbolehkan pengangkatan honorer. Lowongan guru PNS dilakukan dengan pengajuan permohonan dengan system pemetaan yang diselenggarakan oleh Dinas Pendidikan dan Kebudayaan Kabupaten/Kota. Mengelola pendidik dan tenaga kependidikan dilakukan dengan cara pembinaan dan pengembangan tenaga pendidik dan kependidikan agar menciptakan tenaga-tenaga pendidik/kependidikan yang handal serta demi terselenggaranya sebuah pendidikan yang efektif dan efisien. Tugas diberikan kepada masing-masing pendidik sesuai dengan kompetensinya kemudian dievaluasi kinerjanya.

\section{Bidang Sarana dan Prasarana}

Sekolah menetapkan kebijakan mengenai sarana dan prasarana dengan rapat antar guru, komite, dan pemangku kepentingan, Dalam menetapkan kebijakan, beberapa hal yang perlu diperhatikan antara lain: rencana harus disesuaikan kebutuhan, inventarisasinya harus jelas, saranaprasarana yang ada lebih dioptimalkan, menambah sarana dan prasarana baru. Rencana pengadaan sarana dan prasarana ini dilaksanakan dengan hati-hati dan seksama melalui manajemen sarana dan prasarana pendidikan. Pengadaan dilakukan dengan mengajukan proposal ke Dinas Pendidikan. Kebijakan pengelolaan sarana dan prasarana ini juga disosialisasikan kepada seluruh warga sekolah.

\section{Bidang Keuangan dan Pembiayaan}

Sekolah menyusun pedoman pengelolaan biaya investasi dan operasional sekolah dengan melakukan pembentukan tim manajemen yang akan menentukan arah biaya operasional yang disesuaikan dengan petunjuk teknis yang berlaku. Sekolah mensosialisasikan hasil kebijakan saat rapat dewan guru. Pedoman pengelolaan keuangan dan pembiayaan ada di dalam RKAS.

\section{Budaya dan Lingkungan Sekolah}

Sekolah menciptakan suasana, iklim, dan lingkungan yang kondusif dengan membentuk tim sekolah aman. Seluruh tenaga pendidik maupun kependidikan bekerja sesuai dengan tupoksi, membangun komunikasi yang inten dengan seluruh warga sekolah, menerima masukan dan usulan dari bawah, menegakkan aturan secara adil sesuai ketentuan yang ada. Sekolah menetapkan peraturan tentang tata tertip bagi pendidik, tenaga kependidikan, dan peserta didik melalui rapat antara warga sekolah dan komite. Kepala sekolah dan guru senantiasa membimbing, memotivasi, dan memberikan teladan pada peserta didik untuk disiplin dan berkelakuan baik di sekolah. Sekolah harus mampu menanamkan pendidikan karakter, etika, dan nilai-nilai moral.

\section{Peran Masyarakat dan Kemitraan Sekolah}

Sekolah melibatkan warga dan masyarakat untuk mendukung sekolah dalam mengelola pendidikan. Komite sekolah dan orang tua diberdayakan untuk merencanakan kebutuhan, kegiatan, dan anggaran sekolah. Dunia usaha sebagai partner dalam praktik kerja lapangan juga diberdayakan misalnya dengan mengajak peserta didik rekreasi industri untuk melihat 
bagaimana cara membuat kue dan kerajinan. Masyarakat dilingkungan sekolah juga berkontribusi dalam menjaga keamanan sekolah. Kemitraan dengan lembaga pemerintah diwujudkan dalam kegiatan misalnya institusi tertentu diundang sebagai guru tamu, tenaga ahli, atau mereka yang datang untuk mengadakan sosialisasi program tertentu biasanya memberikan pelatihan kepada guru atau sosialisasi tata cara hidup bersih kepada peserta didik. Kemitraan dengan lembaga non pemerintah LSM dilakukan dengan melakukan pelayanan yang baik terutama pelayanan data, transparansi penggunaan dana, atau layanan sosial yang diperlukan. Sistem kemitraan ada yang ditetapkan dengan perjanjian tertulis ada yang normative.

Berdasarkan analisis hasil observasi, dokumentasi, dan wawancara dapat diambil kesimpulan bahwa sekolah sudah membuat pedoman yang mengatur aspek pengelolaan dan pelaksanaan program secara terstruktur dan sistematis. Pedoman pengelolaan yang dimiliki SDN Prambon antara lain tata tertib sekolah, kurikulum sekolah, peraturan akademik, struktur organisasi, dan kalender akademik. Kepala sekolah dan para guru dituntut bertanggung jawab terhadap kualitas proses dan hasil belajar guna meningkatkan mutu pendidikan. Pendelegasian tugas guru, staf, dan kepala sekolah jelas. Tugas kepala sekolah dalam struktur organisasi sekolah antara lain pemimpin, manajer, supervisor, administrator, educator, dan motivator.

Sekolah mengembangkan inovasi dalam memberikan pelayanan pendidikan dan menetapkan kebijakannya sendiri kepada peserta didik. Hal terpenting adalah peserta didik berprestasi, siap diuji, sesuai kompetensi yang ditetapkan. Apabila prestasi peserta didik menurun, masyarakat dapat mempertanyakan kepada kepala sekolah dan para guru yang berwenang (Fitrah, 2017).

\section{Pengelolaan Kepala Sekolah}

Menjadi kepala sekolah harus memenuhi kualifikasi umum dan kualifikasi khusus. Salah satunya adalah berpendidikan sarjana (S1) atau diploma empat (D-IV) kependidikan atau nonkependidikan pada perguruan tinggi yang terakreditasi serta memiliki pengalaman mengajar sekurang-kurangnya 5 (lima) tahun menurut jenjang sekolah masing-masing. Kepala sekolah SDN Prambon menjunjung prinsip ajaran kepemimpinan dari Ki Hajar Dewantara yaitu Ing Ngarso Sung Tulodo (memberi teladan di depan), Ing Madya Mangun Karso (berada di tengah untuk membangun semangat), dan Tut Wuri Handayani (memberikan dorongan dari belakang). Menjadi seorang pemimpin harus mampu memberi teladan yang baik bagi orangorang disekitarnya. Seorang pemimpin harus mampu menciptakan suasana yang kondusif, bergerak bersama, menciptakan program dan berinovasi, memberikan motivasi dan semangat bagi seluruh warga sekolah agar bergerak mencapai tujuan sekolah.

\section{Merumuskan Target Mutu Sekolah}

Tujuan dan target mutu sekolah dirumuskan dalam dokumen kurikulum sekolah. Target mutu dirumuskan dengan menganalisis rapor mutu, mengevaluasi kinerja, melihat potensi, dan melihat peluang. Ide kepala sekolah dibahas dalam pertemuan dewan guru dan komite sekolah.

\section{Analisis Tantangan, Peluang, Kekuatan, dan Kelemahan Sekolah}

Kepala sekolah menganalisis data-data yang ada, sejauh ini tantangan yang harus dihadapai adalah persaingan dengan lembaga pendidikan setingkat dan menciptakan lulusan yang sesuai standar, sekolah selalu mencari peluang dengan berupaya menemukan bakat terpendam peserta didik kemudian melakukan 
pembinaan, kekuatannya warga sekolah mudah dikoordinasi dan banyak peserta didik yang memiliki prestasi yang bagus, kelemahan adalah karena pembiayaan.

\section{Menjaga Motivasi Pendidik dan Tenaga Kependidikan}

Kepala sekolah memastikan pengawasan, pembinaan, reward and punishment berjalan dengan baik, sehingga ada nuansa keadilan bagi tenaga pendidik dan tenaga kependidikan. Bagi yang berprestasi mendapat penghargaan, bagi yang melanggar mendapatkan sanksi/ pembinaan.

\section{Penghargaan dan Sanksi Pendidik dan Tenaga Kependidikan}

Penghargaan diberikan berdasarkan peraturan sekolah yang sudah dibuat. Demikian juga sanksi apabila terjadi pelanggaran disiplin SDN Prambon menerapkan PP 53 tahun 2010 tentang disiplin pegawai. Peraturan sekolah, penghargaan bagi siswa yang memperoleh nilai 100 dalam UN adalah piagam penghargaan dan uang $\mathrm{Rp}$ 100.000,-. Sanksi siswa antara lain:

1) Siswa yang tidak tertib / melanggar peraturan/tata tertib siswa akan diberi sanksi yang sesuai dengan pelanggarannya.

2) Siswa yang kehadirannya kurang dari 85 $\%$ dari kehadiran total tidak diperkenankan mengikuti ujian.

3) Siswa yang tidak diikutsertakan proses penilaian akibat tidak memenuhi kehadiran minimal, dikembalikan kepada orang tua setelah ada pemberitahuan/ peringatan kepada orang tua terlebih dahulu.

4) Ketentuan mengenai sanksi ketidakhadiran dan keterlambatan siswa diatur dalam tata tertib siswa.

Penghargaan Pendidik dan Tenaga Kependidikan. Penghargaan bagi pendidik dan tenaga kependidikan juara lomba:
1) Juara lomba/ berprestasi tingkat provinsi I nasional adalah piagam penghargaan dan uang Rp. 1.000.000,-.

2) Guru mata pelajaran pengajar yang siswanya mendapat nilai UN 100, adalah piagam penghargaan dan uang $\mathrm{Rp}$. 100.000,- atau barang yang senilai

3) Sanksi Pendidik dan Tenaga Kependidikan. Pendidik \& tenaga kependidikan yang melanggar dilakukan pembinaan sesuai dengan peraturan Aparatur Sipil Negara.

\section{Menciptakan Pembelajaran yang Kondusif}

Sekolah menciptkan lingkungan pembelajaran yang kondusif bagi peserta didik dengan membuat lingkungan belajar yang menginspirasi, proses belajar yang efektif dan menyenangkan, sumber belajar dan bantuan belajar yang siap siaga. Upaya lain yang dilakukan adalah dengan menciptakan dan memelihara budaya kerja, budaya belajar, lingkungan kerja dan lingkungan belajar yang kondusif yang didukung oleh seluruh warga sekolah, orang tua, dan stake holder lainnya.

\section{Supervisi Sekolah}

SDN Prambon melaksanakan dan merumuskan program supervisi melalui perencanaan, pelaksanaan, evaluasi dan tindak lanjut. Supervisi dibuat dan dilaksanakan secara baik dan konsisten, sebagai bekal untuk melakukan pembinaan dan pengembangan sekolah selanjutnya. Dari data hasil supervisi akan ditemukan titik lemah, dan sekolah berupaya meningkatkan poin-poin yang belum memenuhi kriteria sehingga ada peningkatan kinerja sekolah.

\section{Memberi Teladan}

Kepala sekolah berupaya memberi teladan bagi warga sekolah dengan cara berdoa kepada Tuhan Yang Maha Esa, menjaga tata tertib sekolah, tidak melanggar kode etik guru dan tenaga kependidikan, bekerja sesuai tupoksi Kepala Sekolah, menjaga sikap dan perilaku sesuai norma yang berlaku di 
masyarakat, menjaga integritas dan menghindari konflik kepentingan, menjalin komunikasi dengan semua pihak, mau menerima masukan, mau belajar dan bekerja keras.

\section{Menjalin Kerjasama dengan Orang Tua Peserta Didik, Masyarakat, dan Komite Sekolah}

Kepala sekolah menjalin kerjasama dengan komite sekolah dan orang tua saat merencanakan kebutuhan di awal tahun pelajaran, perencanaan kegiatan dan anggaran sekolah, kerjasama dengan dunia usaha dan dunia industri untuk meningkatkan keterampilan peserta didik missal dalam seni dan keterampilan, masyarakat lingkungan sekolah berkontribusi dalam menjaga keamanan sekolah agar tercipta jalinan kerjasama dan saling menguntungkan. Kepala sekolah berupaya saling berkomunikasi, saling keterbukaan agar permasalahan dapat terselesaikan.

Berdasarkan analisis peneliti, guru kadang menghadapi permasalahan dalam pemahaman kurikulum 2013, dan kepala sekolah menerapkan kepemimpinannya dengan pendampingan kepada guru saat melaksanakan tugasnya. Manajemen kepemimpinan yang dilakukan oleh kepala sekolah meliputi menentukan target mutu dan mensosialisasikan target mutu kepada seluruh warga sekolah. Kepala sekolah juga menyampaikan tupoksi, membentuk struktur organisasi, mendelegasikan wewenang. Kepala sekolah juga mendampingi guru, memantau guru, mendiskusikan hasil temuan, dan focus pada tindak lanjut.

\section{Pengawasan dan Evaluasi}

Sekolah menyusun program pengawasan secara obyektif, bertanggung jawab, dan berkelanjutan. Supervisi dilakukan secara periodik tiap semester melalui tahapan perencanaan, pelaksanaan, evaluasi dan tindak lanjut hasil supervisi. Untuk membantu pelaksanaan supervisi, kepala sekolah membentuk Tim Supervisi agar bisa menjangkau seluruh guru mapel/ guru bk.
Supervisi juga dilakukan langsung oleh kepala sekolah. Supervisi juga dilakukan oleh guru senior sejawat/tim yang ditunjuk oleh kepala sekolah. Supervisi mandiri oleh guru melalui form yang disiapkan oleh tim.

Hasil evaluasi dilaporkan kepada pengawas pendidikan, komite sekolah, dan pihak-pihak yang berkepentingan. Sekolah melakukan evaluasi terhadap kinerja sekolah. SDN Prambon melakukan evaluasi program secara periodic setahun sekali. Kurikulum di sekolah bersifat komprehensif dan fleksibel dalam mengadaptasi kemajuan ilmu pengetahuan dan teknologi. Evaluasi kurikulum bersifat menyeluruh dan melibatkan berbagai pihak meliputi dewan guru, komite sekolah, dan alumni. evaluasi pendayagunaan pendidik dan tenaga kependidikan direncanakan secara komprehensif pada setiap akhir semester. Evaluasi pendidik dan tenaga kependidikan meliputi kesesuaian penugasan dengan keahlian, keseimbangan beban kerja, dan kinerja pendidik.

Berdasarkan hasil analisis, peneliti mengambil kesimpulan evaluasi di SDN Prambon sudah terlaksana meskipun ada beberapa poin yang belum optimal. Kepala sekolah memiliki berbagai kesibukan sehingga tidak setiap proses belajar mengajar dapat dipantau. Evaluasi berlangsung sekali setahun dengan melibatkan komite sekolah dan selalu ada tindak lanjut apabila ada hal-hal yang harus segera dibenahi.

\section{KESIMPULAN}

Proses pendidikan di SDN Prambon sudah memenuhi kriteria pendidikan yang bermutu yang meliputi: 1) keefektifan kepemimpinan kepala sekolah; 2) partisipasi aktif seluruh komponen yang berkepentingan di sekolah; 3) efektifitas proses belajar mengajar; 4) kurikulum yang relevan; 5) visi, misi, dan tujuan yang terarah; 6) kondusifnya iklim dan lingkungan sekolah; 6) keterlibatan masyarakat dan orang tua peserta didik. Kualitas pendidikan di SDN Prambon berpeluang untuk direvisi secara dinamis dan ditingkatkan sehingga 
mencapai kualitas standar yang semakin meningkat.

\section{SARAN}

Beberapa saran yang diberikan antara lain: 1) perlu adanya peningkatan sosialisasi pengelolaan sarana dan prasarana serta laporan pembiayaan sekolah; 2) perlu peningkatan program pengawasan kegiatan belajar mengajar di kelas; 3) guru perlu aktif memberikan masukan sebagai usaha meningkatkan mutu sekolah.

\section{DAFTAR RUJUKAN}

Arif Widodo, Dyah Indraswati, Deni Sutisna, Nursaptini, S. N. (2020). Identifikasi Bakat Peserta Didik Berkebutuhan Khusus (Pdbk) Di Madrasah Inklusi Kabupaten Lombok. Jurnal Pendidikan Inklusi (JPI), 3(2), 102-116. https://doi.org/http://dx.doi.org/10.2674 0/inklusi.v3n2.p102-116

Arif Widodo, Dyah Indraswati, A. R. (2020). Analisis Penggunaan Media Gambar Berseri Untuk Meningkatkan Kemampuan Membaca Siswa Disleksia Di Sekolah Dasar. Magistra: Media Pengembangan IImu Pendidikan Dasar Dan Keislaman, 11(1), 1-21. https://doi.org/http://dx.doi.org/10.3194 2/mgs.v11i1.3457

Asep Sunandar, Sunarni, D. E. K. (2013). Pola Penjaminan Mutu Pada Rintisan Sekolah Bertaraf Internasional Berbasis Nilai-Nilai Sekolah Asep. Jurnal IImu Pendidikan, 19(2), 230$235 . \quad$ https://doi.org/DOI: http://dx.doi.org/10.17977/jip.v19i2.421 8

Calam, A., \& Qurniati, A. (2016). Merumuskan Visi dan Misi Lembaga Pendidikan. Jurnal IImiah Saintikom, 15(1), 53-68.

Deni Sutisna, Dyah Indraswati, Nursaptini, Setiani Novitasari, M. S. (2020). Penerapan Program Pendidikan Inklusi Di SDN 1 Sangkawana Lombok Tengah. Progres Pendidikan, 1(2),
$115-127$.

Dyah Indraswati, Arif Widodo, Aisa Nikmah Rahmatih, Mohammad Archi Maulyda, M. E. (2020). Implementasi Sekolah Ramah Anak Dan Keluarga Di Sdn 2 Hegarsari, Sdn Kaligintung, Dan Sdn 1 Sangkawana. JKKP: Jurnal Kesejahteraan Kelaurga Dan Pendidikan, 7(April), 51-62. https://doi.org/: http://doi.org/10.21009/JKKP.071.05

Fitrah, M. (2017). Peran Kepala Sekolah Dalam Meningkatkan Mutu Pendidikan. Jurnal Penjaminan Mutu, 3(1), 31. https://doi.org/10.25078/jpm.v3i1.90

Imron, A. (1998). Manajemen Peserta Didik Di SD: Masalah, Penyebab, Dan Alternatifnya. IImu Pendidikan, Vol. 5, p. 26. Retrieved from http://journal.um.ac.id/index.php/jip/arti cle/view/937

Indraswati, D. (2018). Efektivitas Model Pembelajaran Kooperatif Tipe Numbered Heads Together ( NHT ) Terhadap: Kompetensi Sikap Siswa , Kompetensi. Journal Research and Analysis: Economy, 1(2), 52-58. Retrieved from https://journal.stkipsingkawang.ac.id/in dex.php/JRAE/article/view/953

Indraswati, D., Marhayani, D. A., Sutisna, D., \& Widodo, A. (2020). Critical Thinking Dan Problem Solving Dalam Pembelajaran Ips Untuk Menjawab Tantangan. Sosial Horizon, 7(1), 1228.

https://doi.org/10.31571/sosial.v7i1.154 0

Nur, M., Harun, C. Z., \& Ibrahim, S. (2016). Manajemen Sekolah Dalam Meningkatkan Mutu Pendidikan Pada Sdn Dayah Guci Kabupaten Pidie. Jurnal Administrasi Pendidikan Pascasarjana Universitas Syiah Kuala 11, 4(1), 93-103.

Pasaribu, A. (2017). Implementasi Manajemen Berbasis Sekolah Dalam 
Pencapaian Tujuan Pendidikan Nasional Di Madrasah. EduTech: Jurnal IImu Pendidikan Dan IImu Sosial, 3(1), 12-34.

Riyanta, T. (2016). Mengembangkan Budaya Mutu Sekolah Melalui Kepemimpinan Transformasional. Jurnal Manajemen Pendidikan UNY, 12(2), 114301.

Sastradiharja, E. J. (2019). Manajemen Sekolah Berbasis Mutu. Mumtaz: Jurnal Studi Al-Qur'an Dan Keislaman, 2(2), 267-292. https://doi.org/10.36671/mumtaz.v2i2.2 8

Stockard, J., \& Lehman, M. B. (2004). Influences on the satisfaction and retention of 1st-year teachers: The importance of effective school management. Educational Administration Quarterly, 40(5), 742771. https://doi.org/10.1177/0013161X0426 8844

Sukaningtyas, D., Satori, D., \& Udin Syaefuddin Sa'ud. (2016). Pengembangan Kapasitas Manajemen Sekolah Dalam Membangun Pemahaman Visi dan Misi. Jurnal IImu Pendidikan, 22(2), 101-107. Retrieved from

file:///C:/Users/Client/Downloads/872711599-1-PB (1).pdf
Sutisna, D., Indraswati, D., \& Sobri, M. (2019). Keteladanan Guru sebagai Sarana Penerapan Pendidikan Karakter Siswa. Jurnal Pendidikan Dasar Indonesia, 4(2), 29-33. https://doi.org/http://dx.doi.org/10.2673 7/jpdi.v4i2.1236

Usman, A. S. (2014). Peningkatan Mutu Pendidikan Melalui Penerapan Manajemen Berbasis Sekolah. Jurnal IImiah Didaktika, 15(1), 13-31. https://doi.org/http://dx.doi.org/10.2237 3/jid.v15i1.554

Wellisch, J. B., Macqueen, A. H., Carriere, R. A., \& Duck, G. A. (1978). School Management and Organization in Successful Schools. Sociology in Education, 51(July), 211-226.

Widodo, A., \& Indraswati, D. (2019). Analisis Konten HOTS dalam Buku Siswa Kelas V Tema 6 "Panas dan Perpindahannya " Kurikulum 2013. Madrasah, 12(1), 1-13. https://doi.org/http://dx.doi.org/10.1886 0/mad.v12i1.7744

Widodo, A., Indraswati, D., \& Sobri, M. (2019). Analisis Nilai-Nilai Kecakapan Abad 21 Dalam Buku Siswa SD/MI Kelas $V$ Sub Tema 1 Manusia dan Lingkungan. Jurnal Tarbiyah: Jurnal Ilmiah Kependidikan, 8(2), 125-133. https://doi.org/10.18592/tarbiyah.v8i2.3 231 